\title{
PRKCE Gene
}

National Cancer Institute

\section{Source}

National Cancer Institute. PRKCE Gene. NCI Thesaurus. Code C114337.

This gene plays a role in diacylglycerol-dependent signaling. 